\title{
Decay of Fanatical Nationalism in Pakistan: Looking Back to the Election of 1970
}

\author{
Md. Tanziul Islam", Md. Jubaer Ibna Taher², Md. Asaduzzaman Mondol Asad², and Ram Proshad \\ $\operatorname{Barman}^{3 *}$
}

${ }^{1}$ Dept. of Political Science, Begum Rokeya University, Rangpur, Bangladesh; ${ }^{2}$ Dept. of Public Administration, Begum Rokeya University, Rangpur, Bangladesh; and ${ }^{3}$ Dept. of Sociology, Begum Rokeya University, Rangpur, Bangladesh.

*Correspondence: rpbarman@brur.ac.bd (Ram Proshad Barman, Assistant Professor, Department of Sociology, Begum Rokeya University, Rangpur, Bangladesh).

\begin{abstract}
Pakistan and India were bloomed as an independent country in 1947 on the basis of two nation theory of Muhammad Ali Jinnah. He promulgated two nation theories in light of religious dogmatism. Pakistan had been divided into two parts namely East and West Pakistan considering the distance of $1200 \mathrm{~km}$ between two territories. There was no resemblance between these two parts except religious similarities. Later, Bengali nationalism had gradually been developed in West Pakistan through various events i.e., language movement in 1952, United Front election in 1954, 6-point movement in 1966 and the election of 1970. The duration of united Pakistan was the history of exploitation, oppression and deprivation of the East by the West. The present paper attempts to explore how fanatical nationalism had been decaying during the regime of Pakistan. Additionally, the study tries to search out the core consequences of the election of 1970 towards the liberation movement. This paper also provides the evaluation of present politics viewing the historical events as well. Finally, this present study gives some remedial recommendations against the Socio-political problem relevant to the findings.
\end{abstract}

Keywords: Fanatical nationalism, Decay, 1970s, Theory, Election of Pakistan, and Bangladesh.

\section{INTRODUCTION:}

The election of 1970 was the last election of united Pakistan and it helped to disclose the mental view of ruling class of West Pakistan. The franchise got opportunity firstly, to apply their voting right on December, 1970 and January, 1971. Although, majority of the elections were conducted indirectly under the dominated power of military during Pakistan regime, the election of 1970 followed democratic pathways exceptionally. In Pakistan, the election was held in two phases. The voter casted the vote on 29 December about a total of 291 seats of the National Assembly and on 16 December a total of 289 seats of the Provincial
Assembly against their candidate. Natural disaster (cyclones and tidal surges) also hampered that election process in the coastal areas. It was finally held on January 18 where it was 9 constituencies of the National Assembly and 21 seats of the Provincial Council. Mass people became enthusiastic to participate in the politics by means of choosing their own leader, Awami League (AL) had got massive mandate from that election. Concurrently, the result of the election reflecting the mandate of Six Points Program and its importance (Pakistan Observer, 1971a).

The prime purpose of the current study is to scrutinize the dogmatic politics in Pakistan regarding 1970s 
election and its evaluation to the present politics of Bangladesh in light of past experience.

\section{MATERIALS AND METHODS:}

\section{Research gap}

Very few in-depth research and analysis we found regarding decay of fanatical nationalism in Pakistan including various published books and articles. In order to better understanding the manifestation of nationalism during 1970s election, the researcher has composed the article for covering in-depth knowledge about the nationalism. Moreover, to give priority the events of 1970s election towards the foundation of Bangladesh in general sense the article also devised.

\section{Research methods and data collection}

Historical and observational methods have mainly been used in this paper. The researcher has collected data from different secondary sources. Also, we have studied various daily newspapers, periodicals, published books, magazines, statements, and research articles to collect information. Additionally, we have studied the official documents from the ministry of Bangladesh focusing the 1970s elections relevant information.

\section{Conceptual definition of Religion and Nationalism}

In this article, conceptual clarification helps to relate between practical experience and theoretical cognition. From this argument, the study explains some conceptions as theory. Even no human society we found with-out the presence of religious beliefs, starting from antiquity to the current arena. Although there are very few people in the world, who do not believe in a Creator. Everyone acknowledges that there is a force at work at the source of life and the world. Religion is what holds life together. Religion is a vision of life and a system of life that guides man to a better way of life by maintaining harmony with nature (Lord and Mackensie, 1919). For Nationalism, it can be defined as a Product of Political, economic, social and intellectual factors at a certain stage in history, is a condition of mind, feeling or sentiment by a group of people living in a well-defined geographical area(Kohn, 1991).

\section{Legal Framework Order for the 1970 Elections}

After the fall of General Ayub Khan, Yahya Khan ascended to power and issued a legal framework order on 30 March 1970 in preparation for the elections
(Pakistan Observer, 1971b). The study found some features in the legal framework order. Few issues got importance in General election provisions i.e., firstly, ensuring universal suffrage for adults secondly, one person to implement one vote policy and thirdly, determining seats for all provinces based on the population. Again, for the formation of the National Assembly these provisions are considered such as;

1) The number of seats in the National Assembly is 313

2) There will be 300 general seats and 13 reserved seats for women

3) The number of seats in all the provinces will be determined on the basis of population

Thus, Pakistan will be an Islamic republic, democratic rule will be established and the provinces will have autonomy power such kinds of provisions are considered to the constitution whereas, the rule of law and finance will be remained in the hands of the Center.

\section{Participation, Environment and Issues in the Election of 1970}

About 25 political parties participated in the 1970 elections. Of these, 11 were from East Pakistan and 14 were from West Pakistan. The strongest parties were: a) Awami League (AL); b) Pakistan People's Party (PPP); c) National Awami Party; d) Jamaat-e-Islam; e) Jamiyate Ulama-E-Islam; f) Jamiat Ulama-E- Pakistan; g) Nezam-E-Islam; h) Pakistan Democratic Party (Ahmed, 1976). The AL in East Pakistan and the People's Party in West Pakistan were strong enough. The AL was progressive. Again, NAP (Bhasani) and PPP believe in Islamic socialist ideas. Undoubtedly, it was complex to exclude other political parties from any right-wing, left-wing or communist group completely. Because the environment was not remained in favor of AL during the military regime of Pakistan. AL as spokesman of mass people could not get opportunity to campaign in the election freely. The ruler always made impediment on the way of election campaign.

They (the ruler) always attempted to prove that AL was not patriotic and people' oriented political party in light of religious sentiment. The following manifestoes are given by the main political parties of Pakistan below; 
1) In the election of 1970, AL declared their manifesto in favor of mass people on the basis of six points program in 1966, 11 points demands, against the rule and economic exploitation of West Pakistani and promulgation elimination of regional inequality. AL also criticized against the central government regarding their failures of several activities especially natural disaster in 1970.

2) Pakistan People's Party (PPP) also declared their manifesto on behalf of voter based on ensuring strong center government system, establishing Islamic socialism and standing their position against India.

\section{Election Results of 1970}

The election was comparatively held on free and fair. The voter gave the vote peacefully in favor of their candidate. The Daily Ittefaq published news regarding the election of 1979 in its editorial part. The news focused that the general election was the historical event of united Pakistan. There have been many obstacles in its path, many doubts have arisen, many threats and provocations have been developed. Under various pretexts, multifarious pressure on the President has been raised to hold the elections indefinitely. One thing is for sure, however, that if the elections had not been held on the scheduled date, the very foundations of the state would have been shaken and the whole future of the nation would have been plunged into grave uncertainty. The voting power is the power of the people and that power is the highest power of the state. On this day of great test, every patriotic citizen will exercise his power and rights by putting forward the eternal demand for the rights of the deprived East Bengal and keeping in mind the overall welfare of the state (Karim and Akter, 2021; The Daily Ittefaq, 1970).

Table 1: Party-based results of the 1970 general election (National Assembly) (Source: Nohlenand Hartmann, 2001).

\begin{tabular}{|c|c|c|c|c|c|c|}
\hline \multirow{2}{*}{ Political Party Name } & \multicolumn{2}{|c|}{ General Seats } & Reserved & Tribal & Total \\
Women & $\begin{array}{c}\text { East } \\
\text { Pakistan }\end{array}$ & $\begin{array}{c}\text { West } \\
\text { Pakistan }\end{array}$ & $\begin{array}{c}\text { Number of Votes Received } \\
\text { Seats }\end{array}$ & $\begin{array}{c}\text { Area } \\
\text { (Percentage) }\end{array}$ \\
\hline Awami League & 160 & -- & 7 & -- & 167 & 75.11 \\
\hline People's Party & -- & 83 & 5 & -- & 88 & -- \\
\hline Muslim League(Qayyum ) & -- & 9 & -- & -- & 9 & 1.07 \\
\hline Muslim League (Council) & -- & 7 & -- & -- & 7 & 1.60 \\
\hline NAP (Wali) & -- & 6 & 1 & -- & 7 & 2.06 \\
\hline Muslim League (Convention) & -- & 2 & -- & -- & 2 & 2.81 \\
\hline Jamaat-E-Islam & -- & 4 & -- & -- & 4 & 6.07 \\
\hline Jamiat Ulama -E-Pakistan & -- & 7 & -- & -- & 7 & 2.81 \\
\hline Jamiat Ulama-E-Islam & -- & 7 & -- & -- & 7 & 0.92 \\
\hline PDP & 1 & -- & -- & -- & 1 & 2.81 \\
\hline Independent/Non-Partisan & 1 & 6 & -- & 7 & 14 & 3.47 \\
\hline & & & & \multicolumn{2}{|c|}{ Other parties } & 1.25 \\
\hline & 162 & & & \multicolumn{2}{|c|}{ Total: $\mathbf{3 1 3}$} & $\mathbf{1 0 0}$ \\
\hline
\end{tabular}

Table 2: East Pakistan Provincial Council Election Results at a Glance (Source: Nohlen and Hartmann, 2001).

\begin{tabular}{|c|c|c|c|}
\hline Political Parties & General Seats & Reserved Women & Total Seats \\
\hline Awami League & 288 & 10 & 298 \\
\hline Pakistan & 02 & - & 02 \\
\hline National Awami Party (Wali) & 01 & - & 01 \\
\hline Jamaat-e-Islami & 01 & - & 01 \\
\hline Nezame Islam & 01 & - & 07 \\
\hline Independent & 07 & - & $\mathbf{3 1 0}$ \\
\hline Total & $\mathbf{3 0 0}$ & $\mathbf{1 0}$ & \\
\hline
\end{tabular}


Other parties, namely the NAP (Bhasani) National League, the People's Party, the Pakistan National Congress and the Islamic Democratic Party, fielded 47 candidates but did not win any seats (1972).

\section{Politics in Pakistan and its Impact}

The result proved that united in the future Pakistan may be broken down. The people of East Pakistan clearly expressed their view through giving their vote. In one side, the ruler of West Pakistan never agreed to hand over power to AL as the winning party and the other side they denied the result and attempted to involve in conspiracy against mass people's movement. Afterwards, mass people realized that on the basis of religious sentiment united Pakistan can't be established and only separation of Pakistan the way of solution from such crisis.

\section{Victory of Awami League}

Multifarious reasons contributed to the victory of $\mathrm{AL}$ as a large popular political organization. The aspects helped to win the elections are given below;

1) The atrocities, tortured and discrimination committed by the Pakistani regime against the people of East Bengal from the beginning were answered by asking the AL by ballot in the elections (Jahan, 1977).

2) Religious Muslims play a role in conquering the $\mathrm{AL}$ in respecting Islamic ideals in the free campaign (Moniruzzaman, 1988).

3) The AL Manifesto was a symbol of the aspirations of the people of East Pakistan. The manifesto reflected the demands of the people of the region and expressed their overwhelming support for the AL.

4) The personal Image of party Chief Bangabandhu Sheikh Mujibur Rahman also worked behind the AL absolute victory in the 1970 elections. His charismatic leadership, personality, fluently speech easily attracted people to him easily. Later, the people voted for his party and paid respect to him (Khan, 1985).

5) Without AL in the 1970 election none of the parties that participated in the election were as strong as the AL in terms of organization. Finally, the AL easily won a majority in the 1970 elections.
6) The people of East Bengal had already gone against the West Pakistan regime as Pakistan, established in 1947 did not have 23 years of election, the people of East Bengal elected the AL by voting in this election.

7) In the 1965 Pak-India war the western regime fought against India living East Bengal completely unprotected.

8) It was under the leadership of the AL that a sixpoint demand for Bengali's release was raised in 1966. As a result, The Bengalis become rights conscious. This awareness gained greater maturity through the 1970 elections. As a result, AL won the 1970 elections.

\section{Breaking Down of Pakistan}

Some notable and important reasons working behind the breakdown of Pakistan i.e., geographical, social, cultural economic and political. First, there was no similarity between East and West Pakistan in terms of geography. The distance between East and West Pakistan was about $1200 \mathrm{~km}$. There was no communication system except by air. As a result, Pakistan broke up (Sobhan, 2015). Second, the social structure and way of life of the people of East and West Pakistan were different. Language, art, literature, dress, food was all different. There was no similarity in any subject except religion. As a result, the downfall of the state of Pakistan became inevitable (Zaheer, 2001). Third, East Pakistan was basically a colony of West Pakistan. The Pakistani regime has exploited East Pakistan in all respects. Widespread economic inequality existed everywhere in the kingdoms, development, education and industry sectors. Although the 1972 constitution called for the elimination of inequality, it was not implemented in practice. Basically, the history of Pakistan was a history of deprivation, a history of exploitation, a history of oppression. The Pakistani regime runs a steamroller on the people of East Pakistan. As a result, the East Pakistani people jumped into the war of independence (Hossain, 1991). Fourth, after the creation of Pakistan, the first blow came against the Bengali language and culture. As a result, the people of Bengal stood up against it and the language movement of 1952 created a sense of Bengali nationalism, United Front election of 1954. The main driving force of the Six Points of 1971 and the Liber- 
ation War of 1971 was the nationalist consciousness based on the language movement (1971b). Fifth, the people of East Bengal voted for autonomy in the election of 1970. The AL, despite gaining an absolute majority, is reluctant to hand over power. Ultimately, the people of Bengal jumped into the war of independence (Maniruzzaman, 1975). The 1970 election was the only general election in the history of Pakistan and the last chance to create a united Pakistan. The election of 1970 is an important event in the history of Bangladesh's freedom struggle. However, it was through these elections the state of Pakistan died and the idea of Pakistani nationalism was shattered. In this context, Bangabandhu Sheikh Mujibur Rahman said, "You have set only one foot on the road of struggle and not even both the feat" He further said that Bengalis will always live as Bengalis (Loshak, 1971).

\section{CONCLUSION AND RECOMMENDATIONS:}

The election unanimously reflected that two-nation theory was a wrong method about the foundation of Pakistan. Though we have got an independent territory through liberation war in 1971, people of Bangladesh are still trying to ensure their right yet in various sectors. Though, Bangladesh is now economically giant country in the South Asia, economic deprivation is accelerating day by day among the citizen here. Indeed, Corruption, lack of people's participation, absent of rule of law, rule of bureaucracy in the name of democracy, lack of good governance, politicization in the administration and absent of free and fair election are still influencing political environment of Bangladesh. Such phenomenon not only hampers the nation building process but also breaks down the national integration in Bangladesh. Indeed, if we build up a Sonar Bangla which was always dreamt by our father of nation Bangabandhu Sheikh Mujibur Rahman, these things must be kept off from our country. The event of election in 1970 has learned for the ruling class. This event teaches the ruling class to respect the majority. Public opinion has to be given most priority over all issues. The history also teaches the leader power is always temporary. Indeed, autocracy never remains in the long run. National integration may break down for the cause of failure of leadership. That's why, few suggestions are given below for ongoing politics in Bangladesh utilizing past experience.
- Territorial integration is needed to form a united state

- Religion dogmatism should be abolished from the state policy

- All types of discrimination should be eliminated including economic, social, political and culture from the state

- People's participation must be developed in the state

\section{ACKNOWLEDGEMENT:}

Authors would like to acknowledge and give warmest thanks to the Begum Rokeya University, Rangpur authority for providing insightful and valuable suggestions to carry on such kind of particular research. They would also like to thanks colleagues as a whole for their continuous support and understanding while writing this paper.

\section{CONFLICTS OF INTEREST:}

The authors declare that there is no potential conflict of interest (such as honoraria, educational Grants, projects) in the subject matter or materials covered to publish this research paper.

\section{REFERENCES:}

1) Ahmed, M. (1976). Bangladesh: Constitutional Quest for Autonomy. dhaka: UPL. http://www.uplbooks.com/author/moudud-ahmed

2) Hossain, G. (1991). Civil Military Relations in Bangladesh. Academic Publishers.

3) Jahan, R. (1977). Pakistan: Failure in National Integration. 2nd edn. dhaka: UPL.

4) Karim MR., and Akter MS. (2021). The contribution of women in the Bengali language movement (1952): a historical analysis, $B r . J$. Arts Humanit., 3(5), 116-127. https://doi.org/10.34104/bjah.02101160127

5) Khan, A. (1985). Generals in Politics,Pakistan 1958-1982. Calcutta: Vikash Publishing House.

6) Kohn, H. (1991). 'Idea of nationalism : a study in its origins and background.'

7) Lord, H. G. and Mackensie, J. S. (1919). Outline of Social Philosophy., The Journal of Philosophy, Psychology and Scientific Methods. https://doi.org/10.2307/2940592

8) Loshak, Df. (1971). Pakistan Crisis in London. London. 
9) Maniruzzaman, T. (1975). Radical Politics and the Emergence of Bangladesh. dhaka: Bangladesh Book International Ltd.

10) Moniruzzaman, T. (1988). The Bangladesh Revolution And Its Aftermath. 2nd edn. Dhaka. http://www.uplbooks.com/book/bangladesh-re volu $\underline{\text { tion-and-its-aftermath }}$

11) Nohlen, Dieter \& Hartmann, C. (2001) Elections in Asia: A data handbook. https://doi.org/10.1093/0199249598.001.0001
12) Sobhan, R. (2015). 'From to Economics to Two Nations: My Journey to Bangladesh', p. 13.

13) Zaheer, H. (2001). The Separation of East Pakistan. Dhaka: UPL.

14) 'Daily Ittefaq', (1970). December.

15) 'Pakistan Observer', (1971a). January.

16) 'The Dawn' (1971b) .

17) 'Report on General Election, (1972). Pakistan 1970-1971.

Citation: Islam MT, Taher MJ, Asad MAM, and Barman RP. (2022). Decay of fanatical nationalism in Pakistan: looking back to the election of 1970, Asian J. Soc. Sci. Leg. Stud., 4(1), 18-23. https://doi.org/10.34104/ajssls.022.018023 @) $\underset{\mathrm{EY}}{\mathbf{8}}$ 